\title{
The Effect of Treatment of Alstonia acuminata Bark-Based Active Compound on the Hematology and Histology of Tiger Grouper Fish (Epinephelus fuscoguttatus)
}

\author{
Jane L. Dangeubun (Corresponding author) \\ Doctoral Degree, Faculty of Fisheries and Marine Science Brawijaya University \\ E-mail: janelinda0102@yahoo.com
}

Hardoko

Faculty of Fisheries and Marine Science Brawijaya University (Promotor), Indonesia

Andayani S.

Faculty of Fisheries and Marine Science Brawijaya University (Promotor), Indonesia

Risjani Y.

Faculty of Fisheries and Marine Science Brawijaya University (Promotor), Indonesia

Received: March 22, 2013 Accepted: May 9, 2013 Published: May 10, 2013

doi: 10.5296/jab.v1i1.3675 URL: http://dx.doi.org/10.5296/jab.v1i1.3675

\begin{abstract}
Tiger grouper (Epinephelus fuscoguttatus) was very susceptible to the poor environment and therefore, it was weak against infection. A solution to this problem was by increasing immune response of the fish. The objective of research was to understand the effect of Alstonia acuminata on the hematology change in order to increase the survival rate of tiger grouper fish. Research was experimental and conducted at laboratory for 3 months. Parameters observed were the hematology of tiger grouper fish (including leukocyte total, monocyte, neutrophile, and lymphocyte) and the survival rate. Result of research indicated that leukocyte total had increased from day-1 to day-5, but decreased at day-7. The highest
\end{abstract}


level of leukocyte total, monocyte, neutrophile, and lymphocyte was obtained at $200 \mathrm{ppm}$ dose. The highest leukocyte total was found at day-5 precisely for 72,666 cells $/ \mathrm{mL}$, while the lowest was obtained at $0 \mathrm{ppm}$ (control) dose exactly for 24,433 cells $/ \mathrm{mL}$. The highest monocyte percentage was attained at day-5 with $8.67 \%$, while the lowest was obtained at 0 ppm (control) dose with $2.33 \%$. The highest neutrophile was achieved in $200 \mathrm{ppm}$ dose with $11.67 \%$. The highest lymphocyte rate of tiger grouper was known at day-5 with $83.33 \%$, while the lowest was recognized at $0 \mathrm{ppm}$ (control) dose. The highest survival rate was $94.44 \%$ and obtained at $200 \mathrm{ppm}$ dose. Result of research concluded that the treatment of Alstonia acuminate crude extract could influence the hematology and increase the survival rate to $94.44 \%$.

Keywords: Alstonia acuminata active compound, tiger grouper (Ehinephelus fuscoguttatus), hematology

\section{Introduction}

Tiger grouper (Epinephelus fuscoguttatus) was widely distributed in tropical and sub-tropical areas. It was the most favorite seafood with good marketability in the domestic and international markets. It was reasonable to say that the sale value of this seafood was high. Market demand for this commodity was very stable and even increasing from year to year. It was not surprising to say that the cultivation work of tiger grouper was indeed a good prospect. However, main barrier of the cultivation of tiger grouper was its high mortality from rearing stage to harvesting stage. Main causes of high mortality in the cultivation were the high cannibalism and the attack of a certain disease but causing massive death (Ninawe, 2006; Badrelin et al., 2008; Karthupandi et al., 2010).

Fish might be easily susceptible to disease when the water quality was decreased. As a consequence, poor health was experienced among fishes. Intensive cultivation system might cause this risk especially when the seed exceeded the carrying capacity of the environment. One serious disease in cultivation of tiger grouper was the infection from Vibrio pathogen bacteria, mainly $V$. harveyi. During the peak of epidemic, fish immune was deprived, and fish was easily stressed, infected and then dead.

The medication against this fish disease so far had involved medicines and antibiotics, such as oxytetracycline, cananycine, chloramphenicol and terramycin. One earlier research had used other agent, such as tetracycline, for this fish disease (Jun et al., 2010). However, the use of chemicals was instead triggering new problem, respectively environmental pollution (Hameed et al., 2003; Kerry et al,, 1997; Khachatryan, 2006; Rairakhwada et al., 2007). The accumulation of antibiotic residuals in the fish tissue would influence the growth of the fish and its resistance to the agents, and might trigger the presence of immunosuppression (Maqsood et al., 2009).

The natural material of land-based plant was an environmental-friendly alternative to eradicate $V$. harveyi. Research attempted to figure out the effect of $A$. acuminata methanol extract on the hematology change and the survival rate of tiger grouper infected by $V$. harveyi. Hematology was one effective and sensitive indicator to monitor physiological and 
pathological changes in the fish (Kori-Siakpere et al., 2005).

\section{Method}

2.1 The Extraction of Active Substance, and the Experiment of Treating A. acuminata Crude Extract into Tiger Grouper and Infecting Fish with $V$. harveyi

Fresh bark of A. acuminata was taken from the research site at Southeast Maluku District. It was dried, cut into small pieces, ground into fine dust, and macerated at room temperature with methanol solvent for $3 \times 24$ hours. This extract was then partitioned with n-hexane and ethyl acetate solvents by the ratio of solvent to material of $4: 1$.

Tiger grouper was maintained in the 40 liters volume batch with clean water and $150 \mathrm{ppm}$ chlorine. It was neutralized by $75 \mathrm{ppm}$ chemical-grade natrium tiosulfate. Fish was acclimated for 7 days, with adjusted temperature and salinity. Fish was removed into submersion batch and given with immunostimulant of $A$. acuminata crude extract at various doses, such as 0 ppm (normal control), 50 ppm, 100 ppm, 150 ppm, and 200 ppm for 1 hour (based on period length in the result of toxicity test). After submersion, fish was returned to maintenance batch and incubated for 3 days. At day-3, fish was placed again in the extract submersion batch and re-submerged for 1 hour. After this, the challenge test against the density of bacteria $V$. harveyi at $10^{7}$ cells $/ \mathrm{mL}$ was conducted. Observation and measurement were carried out for 7 days to acknowledge leukocyte total, monocyte, lymphocyte, and the survival rate of tiger grouper fish.

\subsection{Parameters Observed}

The procedure of counting leukocyte total was based on Bijanti (2005) and Harikrisnan et al. (2010). The procedure of counting leukocyte differential rate (monocyte, neutrophile, and lymphocyte) was based on Bijanti (2005). The survival rate of tiger grouper was calculated through an equation $=[\mathrm{Nt} / \mathrm{No}] \times 100 \%$, where $\mathrm{Nt}=$ the number of fish in the end of rearing, and $\mathrm{No}=$ the number of fish in the beginning of rearing.

\section{Result and Discussion}

\subsection{Leukocyte Total}

Leukocyte was a component of blood cells which functioned as a non-specific defense to localize and to eliminate pathogen through phagocytosis process (Andayani, 2007). The change of leukocyte total in tiger grouper based on A. acuminata crude extract was shown in Figure 1.

Figure 1 showed that leukocyte total was increased at day-5 to 72,666 cells $/ \mathrm{mL}$ but decreased at day-7 to 71,100 cells $/ \mathrm{mL}$. It changed because appropriate immunostimulant dose could increase the activity of complement substances, opsonine macrophage, phagocytosis, and PMn leukocyte. It also facilitated the elimination of incoming antigens, thus preventing the fatalism of infection. The increased leukocyte total meant that there were humoral and cellular responses of leukocyte in dealing with the bacteria (Erlinger, 2004; Finlay et al., 2006). 


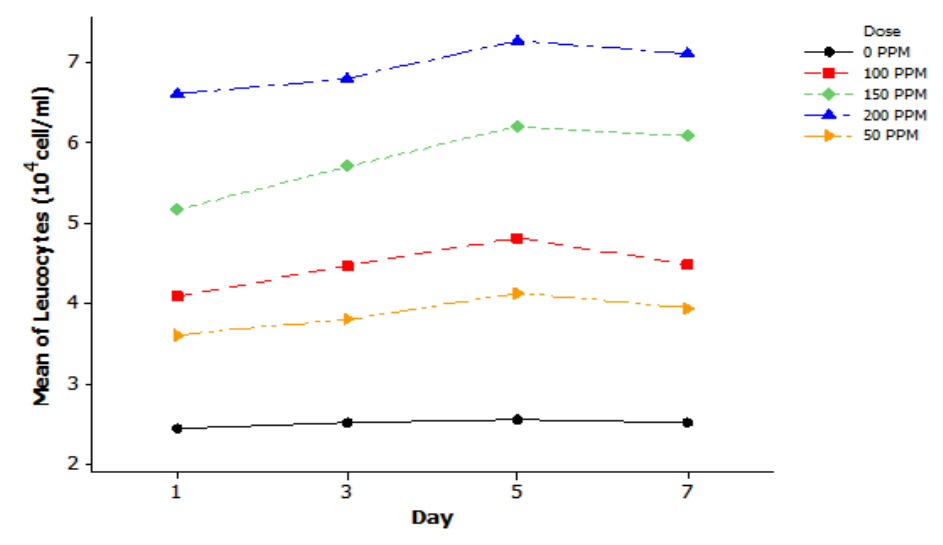

Figure 1. The change of tiger grouper leukocyte total based on A. acuminata crude extract doses

Leukocyte was delivered to the infected part of the body, and it stimulated the fish body to produce defense. At day-7, leukocyte was decreased and it meant that fish body was only sustained until day-5. It was then followed by leukocyte decrease as shown by histological damage in fish body at treatment of extract doses of $50 \mathrm{ppm}, 100 \mathrm{ppm}, 150 \mathrm{ppm}$ and 200 ppm.

The treatment of $A$. acuminata extract influenced the increase of leukocyte total, where 200 ppm dose produced higher leukocyte total if it was compared to $0 \mathrm{ppm}$ (control), $50 \mathrm{ppm}, 100$ ppm and 150 ppm doses. It meant that the higher dose of $A$. acuminata crude extract given to tiger grouper was producing higher leukocyte total in the fish. Indeed, $200 \mathrm{ppm}$ dose was the effective dose of $A$. acuminata crude extract because it could eliminate bacteria $V$. harveyi. It was supported by the fact that body histology of the fish given with $200 \mathrm{ppm}$ dose was only experiencing minor damage of body organ if it was compared to 0 ppm (control), $50 \mathrm{ppm}$, $100 \mathrm{ppm}$ and $150 \mathrm{ppm}$ doses, which these doses were followed by the damage of body organs.

Leukocyte played important role in the fish defense system against pathogen infection (Anderson, 1995). During infection, leukocyte was delivered into the infection system to manufacture fast defense against infectious genetic (Selvaraj, 2009; Buentello et al., 2011). The treatment of $A$. acuminata crude extract definitely helped the defense system of the fish to challenge bacteria infection. Coumaric compound in the A. acuminata crude extract could damage bacterial membrane cells and bind bacterial DNA such that DNA was not expressed, then causing bacteria to death (Lou et al., 2012). Hereby, leukocyte cells were not produced anymore in greater number.

The increased leukocyte population was caused by the increased rate of activities of the cellular division and the production of mitogenic immunostimulant. Mitogenic compounds would activate defense cells for differentiation, and it caused DNA in the lymphocyte cells to 
produce synthesis, thus triggering the increase of leukocyte population (Abbas et al., 2010).

\subsection{Monocyte}

Monocyte played important role in the defense system of fish body. Therefore, research attempted to calculate monocyte rate in tiger grouper fishes. The change of monocyte rate of tiger grouper with A. acuminata crude extract doses was indicated in Figure 2.

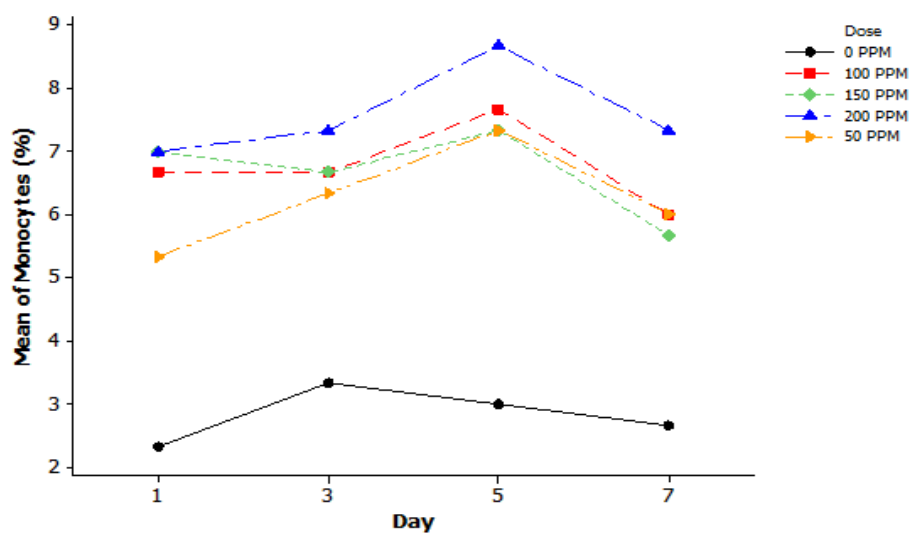

Figure 2. The change of tiger grouper monocyte based on A. acuminata crude extract doses

Figure 2 indicated that $200 \mathrm{ppm}$ dose produced the highest monocyte at day-5 with $8.67 \%$, but decreased at day-7 to $3.0 \%$. Fishes treated with A. acuminata extracts had higher monocyte rate than $0 \mathrm{ppm}$ (control) dose treatment. It was estimated that after the entry of bacteria to infect the fish, monocyte moved fast to leave blood vessel and went to the infected area to activate phagocytosis.

Selvaraj et al. (2005) said that the increase of monocyte during infection might facilitate the monocyte in destructing bacteria. Monocyte represented a cell in the blood flow that was developed into macrophage. After being activated, macrophage had stronger phagocyte capacity than neutrophile, but this capacity was still lower than granulocyte. Maftuch (2007) admitted that the infection might cause inflammation or trigger an antigen-antibody reaction, and all of these would increase the production of monocyte to become a double.

According to Bijanti (2005), monocyte circulation in blood was shorter (1-2 days). This cell (monocyte) migrated into tissues where the cell differentiated further into macrophage. Anderson (1996), Secombes (1996), Bastami et al. (2009), and Harikrishnan et al. (2010) added that the proportion of low monocyte in the leukocyte population could increase to $38 \%$ at shorter term during infection.

\subsection{Neutrophile}

Neutrophile was a phagocyte cell in the polymorphonuclear system. It was a cell that worked fast in the phagocytosis but it did not take long. The change of neutrophile in tiger grouper 
based on A. acuminata crude extract doses was shown in Figure 3.

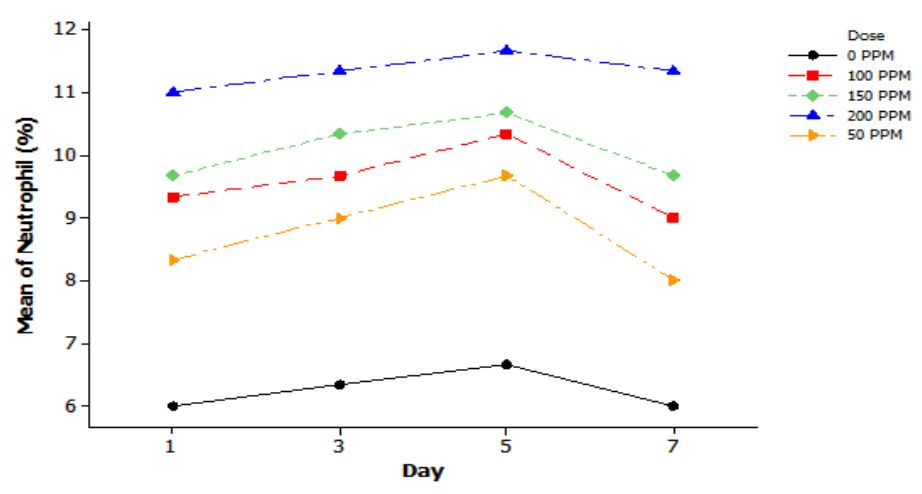

Figure 3. The change of tiger grouper neutrophile based on A. acuminata crude extract doses

Figure 3 showed that 200 ppm dose had produced the highest neutrophile at day-5, which was $11.67 \%$, but it decreased at day-7 to $11.33 \%$. The neutrophile rate of healthy fish was assessed as $6.67 \%$ which remained in the normal range of neutrophile rate from 6 to $8 \%$, as stated by Smith (2007), Neutrophile percentage was increasing during the challenge test. According to Harikrishnan et al. (2010), the neutrophile rate was increased during bacteria infection because neutrophile was coming out from blood vessel and going toward infection region. Main function of neutrophile was destroying the foreign material through phagocytic process. The phagocytosis process involved chemotaxis, the adherence of cell onto infectious particle, the swallowing of this particle by the cell, and the destruction of particle by lysozom enzyme in the phagocom (Tizard, 1989). The exiting of neutrophile from blood vessel during infection was caused by the effect of external chemical stimulation or chemotaxis (Sahan et al., 2007).

This compound was direct immune (killing the bacteria) and stimulant (stimulating the granulocyte). The extract treatment was able to stimulate the increase of granulocyte, and it was proved by the increased number of neutrophile in tiger grouper (Lou et al., 2012). In the neutrophile cytoplasm, there was a granule called lysozom, that was a structure with a density of electron and enzymes such as phosphatase, alkali, lysozym, and aminopeptidase (Abbas et al, 2010). Neutrophile in the blood would increase in number if there was infection and played important role in the first defense of the body (Harikrishnan et al., 2010).

\subsection{Lymphocyte}

Lymphocyte was a cell that functioned to produce antibody, to acknowledge and respond the antigen, and to be a mediator of cellular and humoral immunes (Abbas et al., 2010). The change of lymphocyte in tiger grouper based on $A$. acuminata crude extract doses was displayed in Figure 4. 


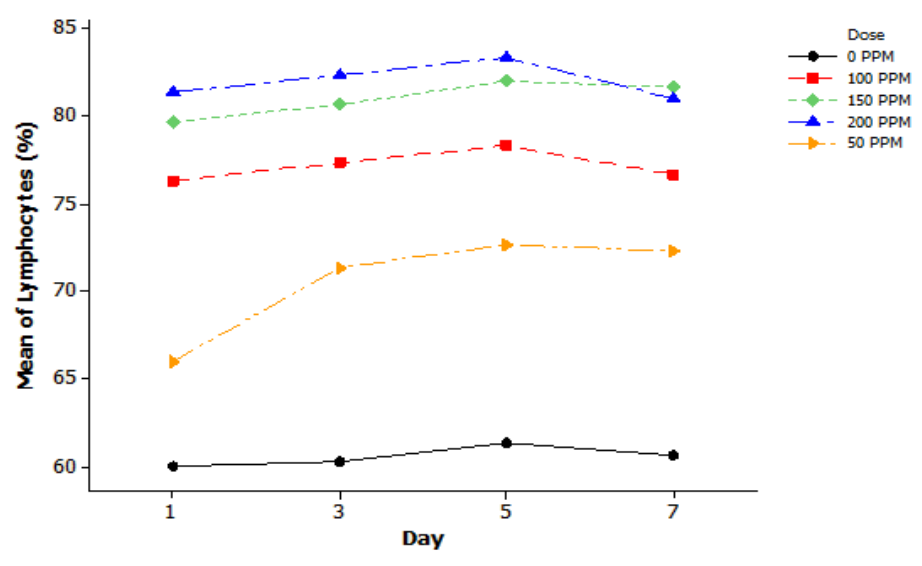

Figure 4. The change of tiger grouper lymphocyte based on A. acuminata crude extract doses

Figure 4 indicated that $200 \mathrm{ppm}$ dose had the highest lymphocyte rate at day-5 with $83.33 \%$, but it decreased at day-7 to $80.32 \%$. The lymphocyte rate in healthy fish was $60.00 \%$, and it was still in normal range of $60-85 \%$ as suggested by Galindo-Vilegas and Hosokawa (2004), but lower than $>80 \%$ as normal range proposed by Smith (2007).

This research determined that the lymphocyte rate was high during challenge test. The normal lymphocyte rate was $60.00 \%$, but it increased to $83.33 \%$. It meant that the humoral immune response of the fish was in good condition such that it always challenged any alien matters and then, established antibody. The mechanism of increasing lymphocyte begun when the lymphocyte in the blood migrated into many lymphs or into spleen. When it met alien matter, lymphocyte developed and conducted a plasmatic cell mytosis to become antibody producer (Mishra et al., 2009).

Provision treatment a dose of 200 ppm can enhance immune system (total leukocytes, monocytes, neutrophyls and lymphocytes). Increasing number of total leukocytes, monocytes, neutrophyls and lymphocytes continues along with the increasing given dose and duration of the infection process. Dominant compound from crude extract of A. acuminata is one of phenolic compounds containing dominant compound p-coumaric acid as basic former of flavonoid compound achieved by substance formation between chalcon and flavon. Enzyme involved in chalcon formation lasted through p-coumaric acid condensation, co-enzyme A with 3 units of malonil co A, so P-coumaric compound take a part as an immunomodulator in stimulating immune respond and direct immune in bacteria killing. This finding corresponds to (Kusmardi et al., 2006) said that flavonoid in the leaf extract of Cassia siamea Lamk and Cassia alata $L$. act as immunomodulator. It shows that the ability of phenolic compounds to enhance phagocytosis can be influenced by other components of the extract that are synergistic to phenolic in enhancing the immune response.

A. acuminata extract helps enhance immune system in fighting bacterial infection in fish. The 
nature of coumaric compound contained in the A. acuminata extract can be destructive to bacterial membrane cells and bind bacterial DNA so that the DNA can not be expressed which in turn leads to bacteria killing (Lou et al., 2012). Therefore total leukocytes, monocytes, neutrophyls dan limphocytes are not reproduced in a large number.

$200 \mathrm{ppm}$ was a high dose treatment in the time of the research conducted and it could increase the total of leukocytes, monocytes, neutrophyls and limphocytes. It is supported by the results of the survival rates at the time of treatment, a dose of $200 \mathrm{ppm}$ appears to produce the highest survival rates 94\%. However, provision of a larger dose than $200 \mathrm{ppm}$ will be able to increase total leukocytes, monocytes, neutrophyls and lymphocytes. This is reinforced by Anderson (1992) that the accuracy of the dose provision is a measure of the success for immunostimulant provision. A high dosage can suppress the body immune system mechanisms and low dosage is ineffective. Similarly, (Li \& Galtin, 2006) said that the length accuracy of the immunostimulatory provision is also very important to enhance optimum immune response because provision of immunostimulant in prolonged periods can suppress the disease resistance and growth of fish.

\subsection{Histopatology of Tiger Grouper's Gill}

Changes in fish tissue due to bacterial attack and the effect of crude extract of A. acuminata as immunostimulant towards control and recovery process of tiger grouper, then performed histological analysis for healthy fish (control) and that has been soaked with crude extract $A$. acuminata.

Condition of Tiger grouper's gill shows histological shape $0 \mathrm{ppm}$ (control) in the feature of filamen and lamella, while gill condition in the bacteria infected fish shows major damage in the lamella indicated by swollen cells and change in the lamella structure. Dosage provision of $A$. acuminata crude extract $50 \mathrm{ppm}, 100 \mathrm{ppm}$ and $150 \mathrm{ppm}$ experience different gill damage. Treatment with crude extract dose of $200 \mathrm{ppm}$ to the gill tissue looks like normal gill (Figure 5). Data of gill tissue damage can be found in Table 1.

Table 1. Gill Tissue Damage caused by provision of $A$. acuminata crude extract

\begin{tabular}{llllllll}
\hline \multirow{2}{*}{ No } & \multirow{2}{*}{ Type of issue Damage } & \multicolumn{5}{c}{ Treatment } \\
\cline { 3 - 8 } & $50 \mathrm{ppm}$ & $100 \mathrm{ppm}$ & $150 \mathrm{ppm}$ & $200 \mathrm{ppm}$ & Bacteria & Normal \\
\hline 1 & Edema & $3,2^{\text {cd }}$ & $2,8^{\mathrm{d}}$ & $2,1^{\mathrm{c}}$ & $1,3^{\mathrm{a}}$ & $3,7^{\mathrm{d}}$ & 1.0 \\
2 & Hyperplasia & $3,2^{\text {cd }}$ & $2,8^{\mathrm{bc}}$ & $2,4^{\mathrm{c}}$ & $1,3^{\mathrm{a}}$ & $3,7^{\mathrm{d}}$ & 1.0 \\
3 & Hypertrophy & $3,3^{\text {cd }}$ & $3,0^{\text {cd }}$ & $2,3^{\mathrm{c}}$ & $1,3^{\mathrm{a}}$ & $3,7^{\mathrm{d}}$ & 1.0 \\
\hline
\end{tabular}

Description:

Score $1=$ minor damage $(0-5 \%), 2=$ moderate damage $(6-25 \%)$,

$3=$ heavy damage $(26-50 \%), 4=$ severe damage $(>50 \%)$.

Letter notation in the score shows real difference at $\alpha=0.05$ 


\section{MInstitute ${ }^{\text {Mut }}$}
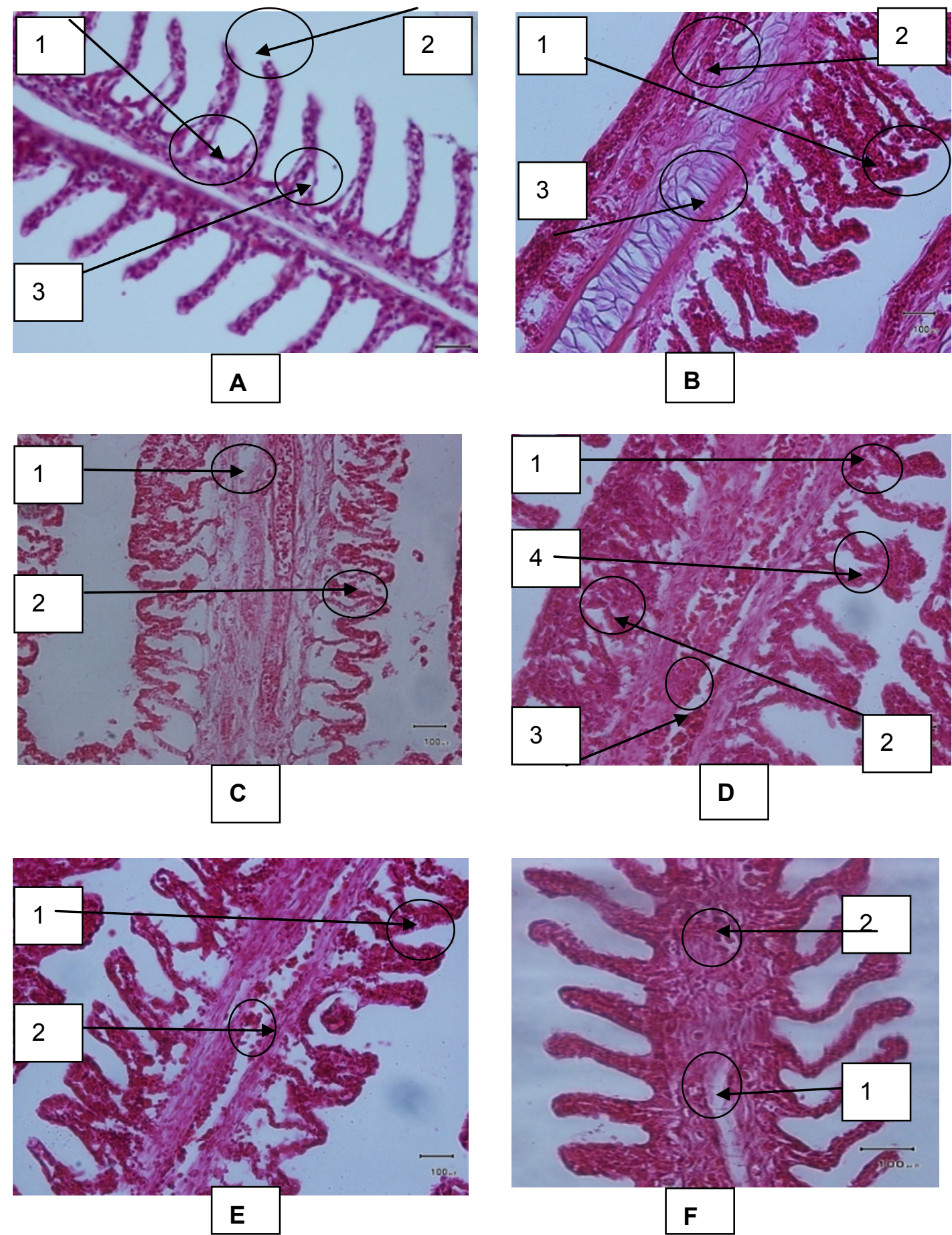

Figure 5. Histopathology of tiger grouper's gill with provision of A. acuminata crude extract Description: (A). Dose of 0 ppm (control), 1. Primary lamella; 2. Secondary lamella 3. Pillar cells, (B). Bacterial control. Arrow no 1. Lamella experience hyperplasia, 2. erythrocyte cells and unification of secondary lamella (C) dose of $50 \mathrm{ppm}$; 1 . Hyperplasia of secondary lamella 2. Pillar cells experience edema (D) dose of $100 \mathrm{ppm} \mathrm{1.} \mathrm{Hyperplasia} \mathrm{of} \mathrm{secondary} \mathrm{lamella,} 2$. Merging secondary lamella, 3. Filamentary edema, 4. Lamella fusion (E) dose of $150 \mathrm{ppm} ; 1$. Hypertrophy, 2. Filamentary edema (F) dose of $200 \mathrm{ppm}$. 1. Filamentary edema, 2. Erythrocyte Enlargement $400 \mathrm{X}$ 
Based on the level of gill tissue damage, bacterial control treatment and dose of $50 \mathrm{ppm}$ experience gill damage of the highest level such as edema, hyperplasia, hypertrophy, while the lowest damage is in the dose of $200 \mathrm{ppm}$, tend to be similar to the treatment of $0 \mathrm{ppm}$ (control). Gill damage as a result of inappropriate immunostimulantt provision, causing non-specific immune system can not work optimally. It leads to tissue damage caused by bacterial infection. The result is consistent with the report Jawetz et al. (1996) stating that too low immunostimulant dosage will influence immune system which in turn can change to toxin.

Dose of $50 \mathrm{ppm}$ and $100 \mathrm{ppm}$ show a heavy tissue damage. Dosage treatment of $150 \mathrm{ppm}$ shows moderate damage. This is proved by scoring in every tissue criteria which is not so high. Gill experience epithelial change can not filter fine particles potential of causing hyperplasia in the secondary lamella and will decrease oxygen uptake in the water (Oluri et al., 2006).

Edema is accumulation of excessive liquid in the intracellular space, while hyperplasia is increase in cell size that causes the merging gill lamella (Mahardika et al., 2004). Price and Wilson (2006) added, increasing hydrostatic pressure tend to force the fluid into the interstitial space so that congestion and edema will possibly to occur simultaneously. Another factor causing edema is the low intravascular osmotic pressure. Plasma cell balance depends on the nature of serum protein osmotic, edema will appear in the low concentration of protein. Edema will lead to tissue enlargement if it attack tissue with inflammation because of the fluid accumulation.

Lamella hyperplasia is usually related to the increasing number and migration of malphigian cells in primary lamella. Gill damage caused by the low water $\mathrm{pH}$ which related to the acid rain and increase in the soil aluminum absorption. Secondary lamella hyperplasia is also related to lamella edema and epithelial hypertrophy. Pillar cell shape changes occur, but the main factor is the increasing number of chloride cells that extends up to the surface of the secondary lamella resulting in thickening of the secondary lamella (Roberts, 2001).

Hypertrophy occurs during fish treatment caused by enlargement in some epithelial cells so as to change the size of the secondary lamella. Further explained by Saloso (2011), gill hypertrophy is caused by the growth and collection of virion in the nucleus. Enlarged nucleus will suppress cytoplasm, huge pressure to the cell membrane exceed cellmembrane elasticity level then caused cellular explosion and lysis.

\section{Conclusion}

Provision of $A$. acuminata can enhance hematological parameter between total leukocytes, monocytes, neuthropyls, limphosytes. A dose of $200 \mathrm{ppm}$ A. acuminata is the highest dose in the treatment and it can enhance hematologycal parameter and survival rate of grouper fish (Epinephelus fuscoguttatus). It is suggested to conduct further research by providing higher dose of A. acuminata $200 \mathrm{ppm}$ towards hematological and hispatologycal condition of tiger grouper fish. 


\section{References}

Abbas, A. K., Licthman, A. H., \& Pillai, S. (2010). Cellular and Molecular Immunology (6th ed.). (pp. 6-38) Philadelphia: W. B. Saunders Company.

Andayani. (2007). Effect of Bioactive Alkaloids Jellyfish (Bougainvillia sp) as immunostimulan against Bactericide Activity, Non-Specific Immune Response and Graduation (RPS) Tiger Grouper (Epinephelus fuscoguttatus). Brawijaya University dissertation. 153 things.

Anderson, D. P. (1992). Immunostimulant, Adjuvant, and Vaccine Carrier in Fish: Application to Aquaculture. Annual Review of Fish Diseases, 21, 281-307. http://dx.doi.org/10.1016/0959-8030(92)90067-8

Anderson \& G. L., Rumsey. (1995). Injection or immersion delivery of selected immunostimulants to trout demonstrate enhancement of non specific defence mechanisms and protective immunity. In M. Sharif, J. R. Arthur \& R. P. Subangsihe (Eds.), Diseases in Asian Acuaculture II. Proceeding of second Symposium on Diseases in Asian Aquaculture. pp. 413-426.

Bastami, K., Moradlou, D., Zaragabadi, A. H., Salehi Mir, S. V., \& Shakiba, M. M., (2009). Measurement of Some Haematological Characteristics of the Wild Carp. Spinger-Verlag London. Comp Clin Pathol, 18, 321-323. http://dx.doi.org/10.1007/s00580-008-0802-7

Badrelin, Ali, G. Bluden, O. Musbah, Tanira, \& Nemmar, A. (2008). Some phytochemical pharmacological and Toxicological properties of Ginger (Zingiber officinale Rolcoe); A Review of recent research science Direct. Food and chemical toxicology, 46, 409-420. http://dx.doi.org/10.1016/j.fct.2007.09.085

Bijanti, R. (2005). Hematology Blood Collection Techniques Fish and Fish Inspection Hematology. Section of the Veterinary Medical Association. Faculty of Veterinary Medicine. Airlangga University. Surabaya.

Buentello Alenjandro, J., Becerril, M. R., Jesus, M., \& Valle, F. A. (2011). Effect of dietary arginine on hematological parameters and innate immune function of channel catfish. Journal of Aquatic Animal Health, 19(3), 195-203. http://dx.doi.org/10.1577/H07-004.1

Cowan, M. M. (1999). Plants Product as Antimicrobial agent. Clinical Microbiology review, $12(4), 564-582$.

Erlinger, T. P. (2004). WBC Count and the Risk of Cancer Mortality in a National Sample of U.S. Adults: Results from the Second National Health and Nutrition Examination Survey Mortality Study. Cancer Epidemiology, Biomarkers \& Prevention, 13, 1052

Finlay, B., \& McFadden, G. (2006). Anti-immunology: evasion of the host immune system by bacterial and viral pathogens. Cell, 124(4), 767-82. http://dx.doi.org/10.1016/j.cell.2006.01.034

Galindo-Villegas, J., \& Hosokawa, H. (2004). Immunostimulants: Toward Temporary 
Prevention of Diseases in Marine Fish (pp. 279-469). Kochi University, Faculty of Agriculture. Laboratory of Fish Nutrition B200 Monobe, Nankoku, Kochi.

Hameed, A. S., Rahaman, K. H., Alagan, A., \& Yoganandhan, K. (2003). Antibiotic resisrance in bacteria isolated from hatchery reared larvae and post larvae of Macrobrachium rosenbergii. J. Aquaculture, 217, 39-48. http://dx.doi.org/10.1016/S0044-8486(02)00298-3

Harikrishnan, R., Balasundaram, C., \& Heo, M. S. (2010). Herbal supplementation diets on hematology and innate immunity in goldfish against Aeromonas hydrophila. Fish \& Shellfish immunology, 27, 508-515. http://dx.doi.org/10.1016/j.fsi.2009.07.004

Jawetz, E., Melnick, \& Adelberg. (1996). Review Of Medical Microbiology (p. 846). Book Medical Publishers.

Jun, W. J., Ji, H. K., Dennis, K. G., Casiano, H. C. Jr., Jee, E. H., Sang, P. S., \& Se, C. P. (2010). Occurrence of tetracycline-resistant Aeromonas hydrophila infection in Korean Cyprinid loach (Misgumus anguillicaudatus). pp. 849-855.

Karuthapandi, B. Xavier Innocent. (2010). Immune responses of Tilapia mossambicus administered with rat serum vaccine for Vibrio anguillarium, Current Biotica, 4(1), 63-72.

Khachatryan, A. R., Besser, D., Hancock, D., \& Call, D. R. (2006). Use of a nonmedicated dietary supplement correlates with increased prevalence of streptomycinsulfatetracycline-resistant Escherichia coli on a dairy farm. Appl. Environ. Microbiol., 72, 4583-4588. http://dx.doi.org/10.1128/AEM.02584-05

Kori-Siakpere, O., Ake, J. E. G., \& Idoge, E. (2005). Haematological characteristics of the African snakehead, Parachacnna obscura. Afr. J. Biotechnol, 4(6), 527-530.

Kusmardi, Kumala S, \& Wulandari D. (2006). Effect of ethanol extract of johar leaf (Cassia siamea Lamk.) Tehadap increased activity and phagocytic capacity of macrophages. Makara, Health, 10(2), 89-93.

Li, P., \& Galtin, D. M. (2006). Nucleotide nutrition in fish: Current knowledge andfuture application. Aquaculture, 251, 141-152. http://dx.doi.org/10.1016/j.aquaculture.2005.01.009

Lou, Z, Wang, H., Rao, S., Sun, J., Ma, C., \& Li, J. (2012). P-Coumaric acid kills bacteria through dual mechanism. Food control, 25, 550-554. http://dx.doi.org/10.1016/j.foodcont.2011.11.022

Maftuch. (2007). Exposure to Vibrio alginolyticus Grouper Rat Intestine Histopathology (Cromileptes altivelis) and The Number And Activity Macrophage Cells. Journal of Fisheries Research, 10(1), 66-70. http/dx.doi.org/10.1016/j.cbpa.2012.05.125

Mahardika, K., Zafran., Johnny, F., \& Roza, D. (2004). Vulnerability level Tiger Grouper (Epinephelus fuscoguttatus) In Different Age Against Infection Iridovirus. Journal of Fisheries of Indonesia. Agency for Marine and Fisheries Research, 10(1).

Maqsood, S., Samoon, M. H., \& Singh, P. (2009). Immunomodulatory and Growth Promoting Effect of Dietary Levamisole in Cyprinus carpio Fingerlings Against the 
Challenge of Aeromonas hydrophila. Turkish Journal of Fisheries and Aquatic Sciences, 9, 111-120.

Mishra, A., Mishra, R., Kumari, P., Murthy, N., \& Naik, B. S. (2009). Antibacterial activity of ethanol Andrographis paniculata, 71(4), 436-438.

Ninawe, (2006). DNA vaccination and prophylactic measures in aquatic health management, Aquaculture. Asia Mag., 21-23.

Olurin, K. B., Olojo, E. A. A., Mbaka, G. O., \& dan Akindele, A. T. (2006). Histopathological Responses of The Gill and Liver Tissues of Clarias gariepunus fingerlings to The Herbicide Glyphosate. African Journal of Biotechnology, 5(24), 2480-2487.

Rairakhwada., Dina, A. K., Pal, Z. P., Bhathena, N. P., Sahu, A., \& Mukherjee, S. C. (2007). Dietary microbial levan enhances cellular non-specific immunity and survival of common carp (Cyprinus carpio). Fish \& Shelfish Immunology, 22, 477-486.

Robert, R. J. (2001). Fish Pathology. Edisi III. W.B.Saunders, London.

Şahan, A., Altun, T., Çevik, F., Cengizler, I., Nevşat, E., \& Genç, E. (2007). Comparative Study of some Haematological Parameters in European Eel (Anguilla anguilla L, 1758) caught from Different Regions of Ceyhan River (Adana, Turkey). Indian Journal of Fisheries and Aquatic science, 24(1-2), 167-171.

Salloso, Y. (2011). Bioactive Compounds brown macroalgae Padina australis as a Natural Antibacterial Control of Vibrio alginolyticus in the grouper aquaculture Rat (Cromileptes altivelis). (p.185). Dissertation Faculty of Fisheries and Marine Sciences UB.

Secombes, C. J. (1990). Isolation of salmonids macrophages and analysis of their killing activity: In J. S. Stolen, T. C. Fletcher, D. P. Anderson, B. S. Robersen \& W. B. Van Muiswinkel (Eds.), Tecniques in Fish Immunology (pp. 137-154). SOS Publications fair Haven.

Selvaraj, V., Sampath, K., \& Sekar, V. (2006). Adjuvant and immunostimulatory effects of b-glucan administration in combination with lipopolysaccharide enhances survival and some immune parameters in carp challenged with Aeromonas hydrophila. Veterinary Immunology and Immunopathology, 114, 15-24. http://dx.doi.org/10.1016/j.vetimm.2006.06.011

Selvaraj, V., Sampath, K., \& Sekar, V. (2009). Administration of lipopolysacharidae increases specific and non-specific immune parameters and survival in carp (Cyprinus carpio) infected with Aeromonas hydrophila. Aquaculture, 286, 176-183. http://dx.doi.org/10.1016/j.aquaculture.2008.09.017

Smith. (2007). Effects of menstrual cycle status and gender on human neutrophil phenotype.

Tizard, I. (1998). An Introduction to Veterinary Immunology. Terjemahan: Mazduki dan S. Hardjosworo. Introduction to Veterinary Immunology (p. 197). Airlangga University. Surabaya. 


\section{Copyright Disclaimer}

Copyright reserved by the author(s).

This article is an open-access article distributed under the terms and conditions of the Creative Commons Attribution license (http://creativecommons.org/licenses/by/3.0/). 